\title{
A Comparative Study of Digital Banking in Public and Private Sector Banks
}

\author{
Natarajan Ramya \\ Assistant Professor \\ AMS School of Informatics, Hyderabad
}

\begin{abstract}
The last two decades within the banking system has seen many developments to face the competition among its competitors. Technology is one field that banking system focuses on for this competition. Nowadays ebanking is that the popular technology employed by banks. E-banking is that the outcome of technological innovations and competition. The customers' satisfaction is additionally vital to face the challenges for the banks to cope up with other banks. Hence this paper focuses on the satisfaction level of consumers towards e-banking services provided by Public and personal Sector banks in. The objectives of this study are to seek out out the factors influencing within the adoption of E-banking provided by public and personal sector banks, identify the extent of satisfaction of customers of public and personal sector banks towards their usage of E-banking. The bank system is facing challenges with stiff competition and advancement of technology. It becomes imperative for service providers to satisfy or exceed the target customers' satisfaction with quality of services expected by them.
\end{abstract}

Keywords: E-Banking, Customer Satisfaction, ATM, Public Sector Banks, Private Sector Banks

\section{Introduction}

Banks in India need to be admired on the enclosure of technology in a large way in their day-today operations. The last two decade has seen many constructive developments within the Indian Banking Sector. Nowadays e-banking is that the popular technology employed by banks. E-Banking means any user with a private computer and a browser can get connected to his bank's website to perform any of the virtual banking functions. E-banking is that the outcome of technological innovations and competition. In fact, banks are using electronic and telecommunication networks for delivering a good range of value-added products and services. As a part of their e-banking initiatives banks offered the following new delivery channels to customer's Automated Teller Machines (ATM)/ Cash Dispensers (CD), Phone banking, Internet banking and Mobile banking. Banks used e-banking as mechanism to fight fierce competition that existed within the market and also to retain the purchasers base, that they had customer's response to e-banking was enthusiastic and followed predicted path of Technology Adoption Life Cycle models.

\section{Need of the sSudy}

In the present globalized scenario, everywhere there's the utilization of technology. In the banking sector also, including the technology play dominate role. In a few years ago, people approached the bank and waited within the long queue for withdrawing cash, requesting a press release of account, transferring the funds etc. so the bank takes many steps to decreases the difficulties and adopt the new technologies of electronic banking service. E-banking includes Mobile banking, Internet banking, and cash machine machine. If the customers use the e-banking services, it is easy to transfer the fund. It ensures convenience (24 hours), user friendliness, safe and secure. Advertisement plays a major role in making people aware of e-banking like Ad in newspaper, Ad in television, Notice etc. These e-banking is taken into account a strong tool for promoting the business. Hence, the researcher made an attempt to study the customer awareness of e-banking

\section{Scope of the Study}

The Scope of research is an overall outline of what the study will cover. The central point of the research is to research the extent of awareness and usage pattern of electronic banking services, customers " perception 
on various aspects of electronic banking service quality, customer satisfaction and continuous service usage intention towards electronic banking services of public and private sector banks. This research is also conducted to suggest some measures to improve the present electronic services which will in turn contribute to the overall improvement in the performance of the banking industry.

\section{Objectives of the Study}

1. To seek out out the factors influencing within the adoption of E-banking provided by public and personal sector banks.

2. To identify the level of satisfaction and major problems faced by the of customers of public and personal sector banks towards their usage of E-banking.

\section{Research Methodology}

The study is based solely on secondary data which was collected from various pre-published articles and research papers that consisted of primary data collected through many field surveys and experiments.

\section{Review of literature}

V. Raja, Joe A. (2020), "Global e-banking scenario and challenges in banking system", This paper is an effort to explore the varied levels of internet banking services provided by banks using the secondary data. It also compares the normal banking systems with net banking. It lists out the various advantages of internet banking and the successful security measures adopted by different banks for secured banking transactions.

Oliveira P., Eric V. H., (2019), "Users as service innovators: The case of banking services" Fond that 55\% of today's computerized commercial banking services were first developed and implemented by non-bank firms for their own use, and 44\% of today's computerized retail banking services were first developed and implemented by individual service users instead of by commercial financial service providers. Manual precursors to those services - manual procedures that administered functions almost like computerized services in our sample - were nearly always developed by users as self-services.

The rise of Internet Banking is also due to its number of benefits for both the provider and the customer as well. From the bank's perspective these are mainly related to cost savings (Sathye, 1999; Robinson, 2000) and internet banking remain one of the cheapest and more efficient delivery channels (see Pikkarainen et al, 2004). Other rationales for the adoption of such services also are associated with competition as internet banking strategy has been a stimulating thanks to retain existing customers and attract new ones (Robinson, 2000) and to the numerous advantages to banks for instance, mass customization, more effective marketing and communication at lower costs amongst others (Tuchila, 2000).

Joseph et al. (2017) examined the influence of internet on the delivery of banking services. They found six primary dimensions of e-banking service quality such as convenience and accuracy, feedback and complaint management, efficiency, queue management, accessibility and customization.

Mishra (2015) in his paper explained the advantages and the security concerns about internet banking. Consistent with him, improved customer access, offering of more services, increased customer loyalty, attracting new customers are the primary drivers of internet banking. But in a survey conducted by the online banking association; member institutions rated security as the most important concern of online banking.

"Banker's Perspectives on E-Banking", Sharma, Himani (2011), This research paper is about the banker's perspectives on e-banking activities of respondents, impact of e-banking and promotional measures employed by banks to market e-banking. The survey data used in this research are collected through a questionnaire in Northern region of India by administering to 192 bankers. The enquiry reveals that customers generally use e-banking services on persuasion of bankers. The bankers are convinced that e- 
banking helps in improving the connection between bankers and customers which it might bring patent improvement within the overall performance of banks.

\section{E-Banking}

E-Banking is part of the broader context for the move to online banking, where banking services are delivered over the internet. The shift from traditional to digital banking has been gradual and remains ongoing, and is constituted by differing degrees of banking service digitization. Digital banking involves high levels of process automation and web-based services and should include APIs enabling crossinstitutional service composition to deliver banking products and supply transactions. It provides the power for users to access financial data through desktop, mobile and ATM services.

A digital bank represents a virtual process that has online banking and beyond. As an end-to-end platform, digital banking must encompass the front that buyers see, the rear end that bankers see through their servers and admin control panels and therefore the middleware that connects these nodes. Ultimately, a digital bank should facilitate all functional levels of banking on all service delivery platforms. In other words, it should have all an equivalent functions as a head office, branch office, online service, bank cards, ATM and point of sale machines.

\section{Customer Satisfaction}

A customer is distinguished from a consumer within the sense that a customer pays for a product or service while a consumer is that the user who experiences a product or service. But in some contexts, a customer and a consumer are often an equivalent . Satisfaction, as widely accepted, is that the consumer's fulfilment response and may be a judgment that a product or service feature or the merchandise of service itself, provided an enjoyable level of consumption-related fulfilment, including levels of under or over fulfilment defines customer satisfaction as a measure of how products or services supplied by a firm meet or surpass customer expectations. Customer satisfaction incorporates such provisions of goods or services that fulfil customer expectations in terms of quality and service, in relation to the magnitude of payment. The study is based on the conceptual model that competency and efficiency of banking services, accurate and timely information, efficient web portal management as well as customer relationship management, demonstration and training of consumers and economy of services offered determine the extent of satisfaction experienced and expressed by E-Banking customers.

\section{Automated Teller Machine (ATM)}

Automated teller machines can offer significant benefits to both banks and their depositors. The machines can enable depositors to withdraw cash at more convenient times and places than during banking hours at branches. At an equivalent time, by automating services that were previously completed manually, ATMs can reduce the prices of servicing some depositor demands. These potential benefits are multiplied when banks share their ATMs, allowing depositors of other banks to access their accounts through a bank's ATM. The decision by banks to share their ATMs is partially determined by the terms under which the sharing would occur. In particular, there are several prices that can be charged to or collected by the three main parties involved in an ATM transaction, the cardholder, the cardholder's bank, and the ATM owner. How, and by whom, these prices are set affects variety of economic decisions, including the amount of machines that banks and non-banks prefer to deploy, deposit market interest rates, distances travelled by depositors and non-depositors that wish to withdraw cash, profits of banks, and welfare of bank customers.

\section{Public Sector Banks}

Public sector banks are those banks where the majority of the stake is held by the government. $51 \%$ of the shares are listed on the stock exchange. Shareholders of private sector banks hold a majority. As per the banking companies act, 14 banks were nationalized in July 1969 and 6 banks were nationalized in 1980.These are called public sector banks. Public sector banks are divided into two categories. Nationalized banks provide public control and control of their functioning to public sector banks. This work is completed in nationalized banks. 


\section{Private Sector Banks}

Private sector banks are those banks where the majority of the equity is held by private shareholder, the government does not have it. Since the liberalization of 1990, old and new private sector banks have evolved in government banking policy. According to the Reserve Bank of India Act and the banking regulation Act, the minimum paid up capital will be Rs. 100 crores with promoters' contribution $25 \%$ or $20 \%$ in case of paid-up capital is more than Rs. 100 crores. The private sector bank will be licensed from the existing policy for opening branches. Then the private sector banks are completely free to open a satisfactory branch without the prior permission of RBI.

\section{Findings}

E-Banking will be successful for banks only when they have Commitment to e-Banking along with a deeper understanding of customer needs. This can come only when the bank has a very big base of customers, best people, and a service attitude. Banks should concentrate on above lines in order to have effective e-banking practices. It is seen that banks are heavily dependent on message alerts to promote their e-banking products and services; it is felt that they should supplement this with other modes like print media, hoardings, email, etc. to stimulate e-banking usage and create greater awareness. There is a need for the bankers to guide and train their customers; additionally, they can also resort to video presentations at bank branches. There should be seminars/workshops/talks on the healthy usage of e-banking, especially for those who are ATM or computer illiterates.

\section{Conclusion}

Finally, I conclude that the increased competition and pressures to cut expenses, banks need to attract and retain their customers by creating, maintaining and highlighting attractive features of e-banking. Results also show that there is a significant difference between the customers' perception about e-banking products and services provided by the public and private sector banks, they are dissatisfied by the services offered by public sector banks in terms of quality and by private sector banks in terms of cost. Therefore, public sector banks need to gear up and improve in terms of latest technology adoption and offering variety of e-banking products with high quality of customer service, as per the expectations of their customers. And private sector banks need to bring down their cost and inform their customer in advance at the time of offering the product(s) or services.

\section{References}

1. Krishnamurthy. and R. Srinivasan (2013), Internet Banking as a tool for Customer Relationship Management - A Study on Customer Perspective, Indian Journal of Research, Volume 2, Issue 2, pp 187-190.

2. Safeena, R., Abdullah and H. Date (2010), Customer's Perspective on E-Business Value: A Case Study on Internet Banking, Journal of Internet Banking and Commerce, Volume 15, No. 1, pp 2.

3. Sharma, H. (2011), Banker's Perspective on E-Banking, NJRIM, Volume 1, No. 1, pp 1-4.

4. Singh, N. P. (2007), Online Frauds in Banks with Phishing, Journal of Internet Banking and Commerce, Volume 12, No. 2, pp 2-8.

5. Bismark Ameyaw and Eric Ashalley (2015), A study on electronic banking and customer satisfaction Volume 20, No. 2, pp 12-19.

6. Andrew Musllme and Mallnga Ramadhan (2011), Internet Banking, customer adoption and customer satisfaction Volume 3, No. 10 , pp 261-269. ) MIJMRD, Vol. I, Issue III, February 2017 ONLINE ISSN-2456-283

7. A.Irudayaraj, (2017), A Comparative Study On Services Provided By Private And Public Sector Banks Towards E-Banking. Volume 8 Issue 82019393 ISSN NO: 1021-9056

8. Prof. (Dr.) Dinesh C. Agrawal1 \& Sakshi Chauhan (2016), A Comparative Study of E-Banking in Public and Private Sectors Banks (with special reference to SBI and HDFC bank in Haridwar). A Peer Reviewed Refereed International Research Journal Volume I, Issue III, February 2017, pp. 01-18 ONLINE ISSN-2456-2831. 
9. Dr. C. Eugine Franco, (2015), A Comparative Study On Satisfaction Of Customers Of Public Sector And Private Sector Banks Towards E Banking.[Glara et. al., Vol.5 (Iss.5: SE): May, 2017] ISSN2350-0530(O), ISSN- 2394-3629(P) ICV (Index Copernicus Value)

10. Vaidya S.,(2014) "Emerging Trends on Functional Utilization of Mobile Banking in Developed Markets in Next 3-4 Years", International Review of Business Research Papers, Vol.7, No. 1, 2011, pp. 301-312

11. Tavaga. (2011). Digital Banking - Meaning, Types, Products, And Services. Retrieved from Journal of Business Management \& Social Sciences Research (JBM\&SSR) ISSN No:2319-5614 Volume2,No.7,July2013.

12. K.Thanga Glara Performance of Indian Public Sector Banks and Private Sector Banks: A Comparative Study. International Journal of Innovation, Management and Technology, Vol. 2, No. 3, June 2011.

13. Mr. Suhair NK (Principal Author)1 , Dr. S Nagasanthi (2017),A Study on Service Quality of EBanking of Private Sector and Public Sector Banks in Kerala. International Journal of Business and Management Invention ISSN (Online): 2319 - 8028, ISSN (Print): 2319 - 801X www.ijbmi.org , Volume 6 Issue 7, July. 2017, PP-01-04

14. Sajun Saha, Hillol Fouzder and Razuan Ahmed Shuvro,(2020),Customer satisfaction in public sector banks and private sector banks in Bangladesh: A comparative study.45 International Journal of Research in Human Resource Management 2020; 2(1): 45-49, E-ISSN: 2663-3361, P-ISSN: $2663-$ 3213,IJRHRM 2020;

15. J. Joshua Selvakumar (2019), Impact of Service Quality on Customer Satisfaction in Public Sector and Private Sector Banks.

16. Dr. Bhupendra Singh Hada (2016) "Online Banking and Customer Satisfaction in Public and Private Sector Banks: Evidence from India" IOSR Journal of Business and Management (IOSR-JBM) e-ISSN: 2278-487X, p-ISSN: 2319-7668. Volume 18, Issue 4 .Ver. II (Apr. 2016), PP 10-20.

17. A. Meharaj Banu, N. Shaik Mohamed, Satyanarayana Parayitam ,Online Banking and Customer Satisfaction: Evidence from India First Published June 13, 2019 Research Article.

18. Poonam Sharma, Research Scholar, Department of Commerce and Management, Poornima University,Jaipur ,Dr. Neha Mathu, A Comparative Study on Public \& Private Sector Banks : A Special Reference to Financial Performance Juni Khyat ISSN: 2278-4632 (UGC Care Group I Listed Journal) Vol-10 Issue-8 No. 2 August 2020.

19. Anis A, Bisht LS, Customer's satisfaction in public and private sector banks in India: A comparative study. Research Paper - Journal of Finance and Marketing (2018) Volume 2, Issue 3.

20. Swati Sharma1, Ishani Patharia Chopra2,A Comparative Study Of Public And Private Banks In India Using Camel Model, 2018 IJCRT | Volume 6, Issue 1 January 2018 | ISSN: 2320-2882 